\title{
A Study of Competitive Advantage through Training and Development in Hospitality Industry with special reference to The Imperial, New Delhi
}

\author{
Sakshi Madaan ${ }^{1}$, Dr. Vinod Kumar Bhatnagar ${ }^{2}$ \\ ${ }^{I}$ Research Scholar, Department of Management, Jiwaji University, Gwalior, Madhya Pradesh, India \\ ${ }^{2}$ Head and Associate Professor, Department of Management, IPS College of Technology and Management, Gwalior, MP \\ *Correspondence: Sakshi Madaan, sakshimadaan4788@gmail.com
}

\begin{abstract}
The Human resource is the key resource of any organization or institute contributing to the economic development of the organization. The employees are required to be effective and efficient in their respective field. To acquire such effectiveness and efficiency, it is the responsibility of the organization to educate and develop the required skills, knowledge and abilities of its employees, as training form a key factor in improving levels of organizational productivity. The focus of the research was to study the usefulness of training programs conducted by The Imperial, identifying the techniques of training being provided to the employees and giving recommendations for the future training programs so as to increase the competitive advantage to the organization. Primary and secondary data were used for collecting information. The primary data was put together with the help of a standardized questionnaire administered to 82 employees selected through simple convenience sampling technique. The questionnaire measured the responses of the employees' pre and posts the training program on Likert scale to check the effectiveness of the training programs organized by the hotel. SPSS has been used and Individual Sample T test and Paired $\mathrm{T}$ test has been used to find the result which shows that the training and development programs organized by The Imperial is effective and there is no difference in the perceived quality of male and female respondents towards training and development of the hotel. Hence, The Imperial is recommended to provide training to the employees relevant to their jobs. In this way there is less consumption of cost, time and energy.
\end{abstract}

Keywords: Training \& development, Effectiveness, Competitive Advantage, Organizational productivity, Economic development.

\section{ARTICLE INFORMATION}

Author(s): Sakshi Madaan, Dr. Vinod Kumar Bhatnagar

Received: 27 Mar, 2021; Accepted: 24 June, 2021; Published: 30 June, 2021;

e-ISSN: 2347-4696;

Paper Id: IJBMR-2021-19;

Citation: 10.37391/IJBMR.090210

Webpage-link:

https://ijbmr.forexjournal.co.in/archive/volume-9/ijbmr-090210.html

\section{INTRODUCTION}

The Indian Hospitality Sector has been observing rare growth trends emerging as one of the driving key factor in the growth of the services sector in India. Since Hotel industry is linked to the tourism industry in a very complex way evolving into a trade which is sensitive to the needs and wishes of people, fueling the growth in Indian Hotel Industry.

Competitive Advantage: Competitive Advantage is an advantage that one firm has over another as its competitors, allowing it to operate and generate greater sales or margins retaining more clients than its opposition.

Competitive advantages give a firm an edge over its opponent partner giving an ability to create superior value for the firm and for its shareholders. The more effective the competitive advantage, it becomes harder for the competitors to offset the advantage. In other words, Competitive advantage is a dominance gained by any organization providing the equitable value as its competitors provided it should be based at a lower price, or it may charge higher prices by offering better value in terms of quality or quantity.

Competitive advantage consequences from corresponding core competencies to the potential prospects.

Good T\&D Leads to Competitive Advantage: Due to increasing competition, the firm is required to constantly revise its product or services, its techniques; managerial/technical skills, thereby increasing productivity. Technological advancements, active competition, sophisticated information technology, knowledge market, globalization, have changed the importance of human resources in organization.

These states of affairs actualize the human capital as the strategic resource of every organization. Differences between the firms exist exactly due to the differences between human capital, i.e. human resources, ways of their management and skill development. In a more and more global, complex and turbulent environment, knowledge is the only reliable foundation for competitive advantage .Hence; human resources are becoming the key factor of business achievements. Human knowledge and skills are the key source for any organizational development, which is why contemporary organizations pay immense attention to their employee development. Thus, employee education and training have become the most favorable answer to survival in 
today's business world. In modern management, the central role is occupied by the human resource department, playing a crucial role. The continuous learning process involves special understanding in the phenomenon of employee training and development. To get hold of its original positions and to attain the competitive advantage, the organization needs to be able to construct or generate knowledge platform, and not rely solely on utilization of the existing ones.

Thus, the importance of continuous employee training and development has a significant role in the development of individual and organizational performance. This study on training program proposes to design a model in which employee training has been sub-divided in three dimensions(Learning experience, Trainer quality, Training design) where-in employee training is the independent variable and competitive advantage is taken as dependent variable which finally results in achieving organizational performance and employee satisfaction.

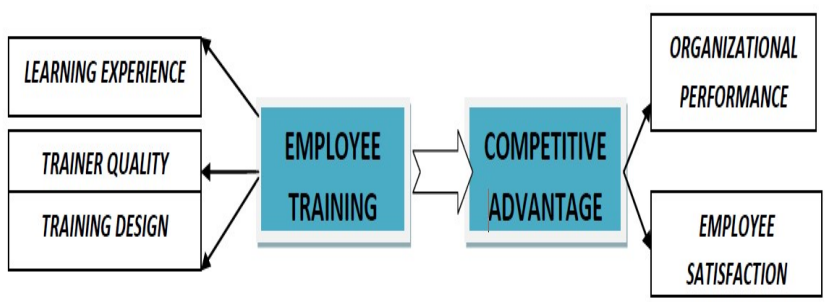

Figure 1: Model of Employee Training that leads to Competitive Advantage.

\section{LITERATURE REVIEW}

Abeeha, B. (2012): Focused on Training \& Development facets include learning experience, training quality and training design. Analysis of the effect of employees training has been recorded to understand as to how it brings competitive advantage to an organization. Data collection was done from 250 employees' for statistical analysis including descriptive frequencies, percentage, standard deviations, mean, average, correlation, and regression were used using SPSS. It was estimated that workers cannot produce better achievement till than they are contented with their employment and it is because of suitable training and progress. Result revealed positive relations between training \& development and competitive advantage. On the basis of these outcome, it has been concluded and recommended that for deriving job satisfaction, trainer quality, training design and learning experience shall be given due consideration.

Afaq Fakhar, et al. (2011): Examined the relationship between training courses and employee presentation at the Pearl Continental (PC) Hotel, Karachi. Training factors like time spent on training and overall scores achieved in training examinations including, age, gender, experience, has been studied in respect to their impact on six different performance dimensions. Primary data was collected through a questionnaire .Data was analyzed with the help of multiple regression model. A significant relationship was found between the two variables; stating that the employees provided with the specific trainings were more competent in performing different task /duties and vice versa. The study recommends conduction of needs assessment, design, development and delivery of training programs for overcoming prevalent problems as a right system approach.

Akhila k., et al (2011): This study provided in-formation evaluating and improving the effectiveness of training. According to this paper the efficiency of an organization depends upon a very important factor that is effective training, which further depends upon the potential of its employees. It was identified that for an effective training evaluation, there must be appropriate training and development specifically made for the individual pertaining to the prevailing conditions. Back planning model occurring in reverse order continuing in cyclic process was found similar to Kirkpatrick's model. The authors identified 5 Key elements of training program effectiveness which are Training environment, Training Design and Development, Training Delivery, Training Implementation and Training Evaluation.

Alexandros G.S., John B. (2007): studied the relationship between perceived employee training effectiveness and job satisfaction, motivation and commitment. Responses of 134 employees and managers were studied and analysed. The results indicated significant correlation between the employees perceived training effectiveness and their commitment, job satisfaction and motivation. Additionally, these three variables were found to have high correlations amongst them. The implications of this study for managers and especially for Human Resource professionals are quite significant, affecting positively on key employee attitudes, which appear to be related to organizational performance outcomes including, productivity, turnover and absenteeism.

Hamid Sheeba (2011): This study was based on a public sector organization, Uttar Pradesh State Tourism Development Corporation and the training initiatives made by the emphasizes the importance of training as an important human resource development vehicle in the present day competitive world with the growing realization both in industry and government circles that training holds the key to unlocking potential economic growth opportunities to achieve a competitive advantage in the tourism industry. The study provided suitable suggestions to evolve meaningful, relevant and effective training programmes that match the job profiles of various categories of employees of the Corporation so that the Corporation improves its efficiency and effectiveness in order to cater to the requirements of the national and international tourist.

Hafeez S.S., Waheed A. (2008): The paper studied value chain model discussing the factors of productivity, highlighting the tactical linkage between training, productivity 
and competitive strategy of the organization. The role of training effectiveness as a moderating variable between training intervention and competitive strategic results was emphasized. The paper also analysed the implications of 'value chain model' evaluating strategic training needs/objectives in line up with the basic competitive strategy and objectives of the organization. This paper has theoretical as well as managerial implications on developing strategic training programs aimed at high productivity and competitive advantage.

Jadhav, A. (2008): Analyzed the existing training and development programmes in banks and their impact on efficiency of employees to cater to the need of their customers. Questionnaire was used for collection of primary data by the bank employees. Random sampling technique was used and sample size was 40. Major findings were most of the respondents have attended in house training and in some cases training was provided at regional or/and head office where the duration of the compulsory training programmes was from 2 days to 15 days. It was concluded that there is increase in efficiency of the private and public Indian banks who conducts training and development programmes for their employees, enhancing their knowledge and skills to satisfy the customers.

Khadijat, A. Y. (2010): investigated the impact of investment in human resource training and development on employees' effectiveness in Nigerian banks. The collected data was examined using descriptive and inferential statistics. Techniques of analysis used were correlation, regression, means and standard deviation. The results indicated that the Bank had the best Human Resource Management. Orientation on the job training, skills improvement training, utilization of the newly acquired skills, regular training and acquisition of job experiences were recognized as training and development behavior in all areas of banking. It was found that the assessment of training and development activities in their banks were based on length of service and job status.

However, the respondents were not significantly different in their assessment of training and development activities based on qualifications. This paper also recommends that Nigerian Banks should evaluate the quality of their human resource frequently providing adequate training providing opportunities to their employees.

Srimannarayana (2006): Presented the measures of training and development that were considered exceptionally valuable and those that were consistently used by HR/training professionals. Based on data accumulated from $\mathrm{HR}$ professionals from different industries, feedback of the training programs were found and the sample was put together on the basis of convenient sampling method and T-test was used. In various training programs, training costs and count of training days were more popular measures when compared to learning measures during training, transfer of training, performance improvements because of training, and cost and benefit analysis of such programs. It was time to focus on impact measures, with already having made significant progress with respect to traditional measures of training and development.

Sum Vichet (2012): This paper studied and analyze the impact of training, on the firm's competitiveness, using the resourcebased research as the theoretical background, keeping in mind firm's business strategies. The survey was conducted on training professionals employed in small, medium, and large firms across three different industries. Regression analysis was done on the collected data revealing a statistically significant positive regression coefficient.

Vijayaraj M., Et al (2012): The research was conducted to know the effectiveness of training in Godrej Sara lee ltd. To measure the training effectiveness of the employees, five factors were taken which mainly includes objectives and needs, session voice, training aids, post training factors and performance. The employee's opinions were qualitative in nature. Descriptive research was used for the study utilizing both Primary and secondary data .Primary data was collected through questionnaire. 50 employees were selected as samples. The tools used for the study were z-test, correlation, and chisquare and percentage method. It was found that the training programme was not so effective. The main problem was the objectives and needs were not clear to the employees and training needs were not very effective. Session voices were satisfactory. The overall performance of the training was not good. Employees' being greatest asset of an organization should be taken care of since the organization achieves their goals through the employees.

\section{OBJECTIVES}

The objectives of the study are:

(a) To Study the Training and Development Policies, Processes and Practices adopted by the Imperial.

(b) To study the effectiveness of training and development program organized by The Imperial, New Delhi, for achieving Competitive Advantage.

(c) To Analyze the Effectiveness of Training Programs with Special Reference to Gender of the employees of the Imperial, New Delhi.

(d) To make recommendations for the future training programs so as to increase the competitive advantage to the organization.

\section{METHODOLOGY}

By the research, we can suggest to the company who is in retail that there has to be a more effective way in dealing with business by using proper automotive techniques. The trends can give potential to the startup company and can take leverage on the existing infrastructure at large. We can say that with the proper use of the technologies we can change the customer perspective towards purchasing a product or a 
service at large. Enterprise Resource Planning software can have a significant impact on the overall prospects of the company when dealing in business.

Methodology used for Data collection: Three methods were used for obtaining information for the study, i.e. Available records which includes books, journals, research papers and internet forming Secondary source of information and primary data was collected through questionnaire from the employees of Imperial.

Sample Size: The study was conducted on 100 employees. Out of which few were rejected due to misleading information and hence 82 were considered for analysis.

Scale Used: 5 point Likert scale was used.

Sampling Technique: Convenience sampling was used as the study is not restricted to any specific department.

(a) Methodology used for Data Analysis:

Technique used for data collection: Technique proposed to be used for Data Analysis was T- test. The t-test is a statistical test to check equality of two sample means (averages) or proportions. To check the effectiveness, Paired sample T- test was used for training and development program organized by The Imperial, New Delhi. Independent sample T- test was analyzed to check the difference in perceived/ experienced quality of training and development, The Imperial, New Delhi by male and female respondents.

Tool used for data collection: SPSS Statistics is a software package used for statistical analysis. It is a broad and flexible statistical analysis for data management solution.

\section{Hypothesis:}

Ho1: Training and Development program organized by The Imperial, New Delhi was not effective.

H1: Training and Development program organized by The Imperial, New Delhi was effective.

Ho2: There is no significant difference in the perception of training effectiveness between male \& female employees of The Imperial, New Delhi.

H2: There is a significant difference in the perception of training effectiveness between male \& female employees of The Imperial, New Delhi.

\section{ANALYSIS}

Demographic profile of the respondents
Table 1: As per Gender

\begin{tabular}{|c|c|c|}
\hline S. No & Gender & Percentage (\%) \\
\hline 1. & Male & $\mathbf{6 6 . 6 7 \%}$ \\
\hline 2. & Female & $\mathbf{3 3 . 3 3 \%}$ \\
\hline
\end{tabular}

Table 1: Reveals that majorities of the respondents were males $(66.67 \%)$ while female respondents constituted only $33.33 \%$.

Table 2: As per Age

\begin{tabular}{|c|c|c|}
\hline S. No & Age (In Years) & Percentage (\%) \\
\hline 1. & $25 \&$ below & $23.33 \%$ \\
\hline 2. & $26-35$ & $36.67 \%$ \\
\hline 3. & $36-45$ & $25 \%$ \\
\hline 4. & $46-$ plus & $15 \%$ \\
\hline
\end{tabular}

Source: Survey result

Table 2: A majority of $36.67 \%$ employees were within the age of $26-35$. $25 \%$ employees were within the range of $35-40$ years of age. $23 \%$ employees were below $25 \&$ the remaining $15 \%$ were above 46 .

Table 3: As per Marital Status

\begin{tabular}{|c|c|c|}
\hline S. No & Gender & Percentage (\%) \\
\hline 1. & Married & $63.33 \%$ \\
\hline 2. & Unmarried & $36.67 \%$ \\
\hline
\end{tabular}

Source: Survey results

Table 3: A majority of $63.37 \%$ were married and remaining $36.67 \%$ were unmarried.

Table 4: As per Work Experience

\begin{tabular}{|c|c|c|}
\hline S. No & $\begin{array}{c}\text { Experience } \\
\text { (In Years) }\end{array}$ & Percentage (\%) \\
\hline 1. & More than 7 years & $40 \%$ \\
\hline 2. & $4-6$ & $32 \&$ \\
\hline 3. & $2-4$ & $22 \%$ \\
\hline 4. & $0-2$ & $6 \%$ \\
\hline
\end{tabular}

Source: Survey result

Table 4: A majority of $70 \%$ employees had a work experience of more than 7 years and above, while $27 \%$ had a work experience of 4-6 years, $19 \%$ employees had a work experience of 2-4 years and $4 \%$ had a work experience of 0 -2 years. 
Table 5: As per Educational Experience

\begin{tabular}{|c|c|c|}
\hline S. No & Qualifications & Percentage (\%) \\
\hline 1. & Graduate & $10 \%$ \\
\hline 2. & Post Graduate & $11.67 \%$ \\
\hline 3. & Professional Qualification & $18.33 \%$ \\
\hline
\end{tabular}

Source: Survey result

Table 5: A majority of $70 \%$ employees were graduate, $18.33 \%$ holds professional degree and remaining $11.67 \%$ were post graduate.

Table 6: As per monthly Gross Income

\begin{tabular}{|c|c|c|}
\hline S. No & Income (In rupees) & Percentage (\%) \\
\hline 1. & $10,000-15,000$ & $21.67 \%$ \\
\hline 2. & $15,001-20,000$ & $40 \%$ \\
\hline 3. & Above 20,000 & $38.33 \%$ \\
\hline
\end{tabular}

Table 6: It states the monthly gross income level wherein $40 \%$ of employees fall under the category of $15000-20,000,38.33 \%$ above 20,000 and remaining $21.67 \%$ above 20,000 range.

Table No: 7 Paired Sample

\begin{tabular}{|l|c|c|c|c|}
\hline & Mean & N & Std. Deviation & Std. Error Mean \\
\hline $\begin{array}{l}\text { Expected } \\
\text { Experienced }\end{array}$ & 85.350 & 82 & 6.92796 & .83682 \\
\cline { 2 - 5 } & 80.250 & 82 & 6.12069 & 1.87919 \\
\hline
\end{tabular}

Source: Survey results

Table 7.1: Output of Paired Sample T- test

To check the effectiveness of training and development program organized by The Imperial, New Delhi,

Table 7: Paired sample $T$ test was used to check the effectiveness of training and development program organized by The Imperial, New Delhi. The value of $t$ is -2.842 and its corresponding significance value is .006 which is less than .05 level of significance so null hypothesis ( $\mathrm{H} 01)$ is rejected and alternate hypothesis (H1) is accepted which means that the training and development program organized by The Imperial, New Delhi was effective (Table 7.1)

\begin{tabular}{|c|c|c|c|c|c|c|c|c|c|}
\hline & & \multicolumn{5}{|c|}{ Paired Differences } & \multirow[t]{3}{*}{$\mathbf{T}$} & \multirow[t]{3}{*}{ df } & \multirow{3}{*}{$\begin{array}{c}\text { Sig. } \\
(2- \\
\text { tailed) }\end{array}$} \\
\hline & & \multirow[t]{2}{*}{ Mean } & \multirow[t]{2}{*}{$\begin{array}{c}\text { Std. } \\
\text { Deviation }\end{array}$} & \multirow[t]{2}{*}{$\begin{array}{l}\text { Std. Error } \\
\text { Mean }\end{array}$} & \multicolumn{2}{|c|}{$\begin{array}{l}95 \% \text { Confidence Interval } \\
\text { of the Difference }\end{array}$} & & & \\
\hline & & & & & Lower & Upper & & & \\
\hline $\begin{array}{l}\text { Pair } \\
1\end{array}$ & $\begin{array}{l}\text { expected - } \\
\text { experienced }\end{array}$ & -2.75000 & 7.49604 & .96774 & -4.68643 & -.81357 & -2.842 & 59 & .006 \\
\hline
\end{tabular}


Table No 8: Group Statistics

\begin{tabular}{|l|c|c|c|c|c|}
\hline & Gender & N & Mean & Std. Deviation & Std. Error Mean \\
\hline Experienced & 1.00 & 40 & 70.3500 & 5.92496 & .93682 \\
& 2.00 & 20 & 69.9000 & 5.72069 & 1.27919 \\
\cline { 2 - 6 } & & & & & \\
\hline
\end{tabular}

Table No 8.1: Output of Independent Sample T- test

\begin{tabular}{|c|c|c|c|c|c|c|c|c|c|c|}
\hline & \multicolumn{2}{|c|}{$\begin{array}{c}\text { Levene's } \\
\text { Test for } \\
\text { Equality of } \\
\text { Variances }\end{array}$} & \multicolumn{7}{|c|}{ T-test for Equality of Means } \\
\hline & & \multirow[t]{2}{*}{$\mathrm{F}$} & \multirow[t]{2}{*}{ Sig. } & \multirow[t]{2}{*}{$\mathrm{T}$} & \multirow[t]{2}{*}{ Df } & \multirow[t]{2}{*}{$\begin{array}{l}\text { Sig. (2- } \\
\text { tailed) }\end{array}$} & \multirow[t]{2}{*}{$\begin{array}{c}\text { Mean } \\
\text { Difference }\end{array}$} & \multirow[t]{2}{*}{$\begin{array}{l}\text { Std. Error } \\
\text { Difference }\end{array}$} & \multicolumn{2}{|c|}{$\begin{array}{l}95 \% \text { Confidence } \\
\text { Interval of the } \\
\text { Difference }\end{array}$} \\
\hline & & & & & & & & & Lower & Upper \\
\hline \multirow[t]{2}{*}{ Experienced } & $\begin{array}{c}\text { Equal } \\
\text { variances } \\
\text { assumed }\end{array}$ & .005 & .943 & .280 & 58 & .780 & .45000 & 1.60451 & $\begin{array}{c}- \\
2.76177\end{array}$ & 3.66177 \\
\hline & $\begin{array}{c}\text { Equal } \\
\text { variances } \\
\text { not } \\
\text { assumed }\end{array}$ & & & .284 & 39.334 & .778 & .45000 & 1.58554 & $\begin{array}{c}- \\
2.75619\end{array}$ & 3.65619 \\
\hline
\end{tabular}

Source: Survey results

Table 8.1: Independent sample T -test was performed to check the significant difference in perceived/experienced effectiveness of Training and Development of The Imperial, New Delhi by male and female respondents . The t value is .280 and its corresponding $\mathrm{p}$ value is .780 which is greater than .05 level of significance, so the null hypothesis (H02) is accepted which means there is no difference in perceived/ experienced quality of male and female respondents towards training and development programs organized by The Imperial, New Delhi. Both the male and female employees have taken the training experience positively and both the genders believe that training has brought a favorable change in the learning, behavior and outcome of the employees (Table 8.1).

\section{CONCLUSION}

The majority employees are satisfied with the training provided to them and think that training improves their skills and makes them more efficient compared to the employees who have not received training. Thus, training and development organized by the hotel is effective and gives the firm competitive advantage over its competitors. The four elements of training and development programs that are studied in this research are learning, behavior, outcome and efficacy. All these elements lead to firm's competitiveness. Thus, the training and development programs organized by The Imperial makes employees more skillful which leads to customer satisfaction and thus gives the hotel a competitive edge in the market. Also, both the male and female employees have taken the training experience positively and both the genders believe that training has brought a favorable change in the learning, behavior and outcome of the employees.
Since training and development is very crucial for any organization for achieving competitive edge over its competitors so:

- The training programs that are organized should be relevant and the learning that will be gained should justify the cost spent for organizing that program and for arranging resources to conduct the program.

- Training sessions, thus, training should be appropriate in its duration.

- The new skills that are being imparted to the employees through training should be well rehearsed and test- checked by the trainer to ensure the proficiency of the employees.

- All the training programs organized by the hotel should improve the overall quality of performance of the employees.

- Training need analysis should be done and then the employees should be considered for attending the training program to avoid wastage of company's financial and physical resources.

\section{RECOMMENDATIONS}




\section{REFERENCES}

[1] Afaq F., Yusoff R., Khan A., Azam K., Thukiman K., (2011), "Employees Training and Performance Relationship in Hospitality Sector A Case of Pearl Continental Hotel, Karachi, Pakistan" International Review of Business Research Papers, Vol 7. No 3,149-158.

[2] Agarwal V., (2011), "Training \& Development in Public Organization with Reference to LIC, INDIA". Gurukul Business Review (GBR), Vol. 7, 87-95.

[3] Batool A., Batool B., (2012), "Effects of employees training on the organizational competitive advantage: Empirical study of Private Sector of Islamabad, Pakistan." Far East Journal of Psychology and Business, Vol. 6 No. 1, 59-72.

[4] Bhatia, S.K, (2005), Training and Development: Concepts and Practices (PP, 3-28, 208), New Delhi; Deep and Deep Publications Pvt Ltd.

[5] Bhattacharya, D.K., "Research Methodology", Excel Books (1 ${ }^{\text {st }}$ edition).

[6] Clementine F., (2003), "Cost-Effective Training and Development Programs in the Hotel Industry during a Recessionary Period". UNLV Theses/Dissertations/Professional Papers/Capstones, 1-37.

[7] Gupta, S.P., "Elementary Statistical Methods", Sultan Chand \& Sons (edition $17^{\text {th }}$ ).

[8] Hamid S., (2011), "A Study of Effectiveness of Training Programs UPSTDC, India- An Analysis". South Asian Journal of Tourism and Heritage, Vol 4, No 1, 72-82.

[9] Janakiram, B (2008), Training and Development (PP, 104-117, 126), New Delhi; Biztantra.

[10] Kothari, C.R., "Research Methodology". New Age International Publishers (2nd edition).

[11] Kumar, R. (2005), Research Methodology, (PP, 37-45), New Delhi; Anurag Jain Excel Books.

[12] Kunche A., Puli R., Guniganti S., Puli D., (2011), "Analysis and Evaluation of Training Effectiveness". Human Resource Management Research, Vol 1, No. 1, 1-7.

[13] Rathore A., Maheshwari N., (2013), "Assessment of Training Needs For the Hospitality Industry: A Case Study of Hotels in Rajasthan". South Asian Journal of Tourism and Heritage, Vol. 6, No. 1, 128- 136.

[14] Sahinidis A., Bouris J., (2007), "Employee perceived training effectiveness relationship to employee attitudes". Journal of European Industrial Training Vol. 32 No. 1, 63-76.

[15] Sharma A., Narang G., (2012), “Achieving Competitive Advantage through HR Practices". National Conference on Emerging Challenges for Sustainable Business, 751- 766.

[16] Siddiqui S., Asghar W., (2008), "Linking Training, Productivity and Competitive Strategy: Implications of Value Chain Model for Strategically Effective Training Programs". International Review of Business Research Papers, Vol. 4 No.1, 310-324.

[17] Sowjanya G., Rajasekhar M., (2012), "Effectiveness of Employees' Training and Development in Manufacturing Industries (A Case Study of East Godavari District, Andhra Pradesh)". Global Research Analysis, Vol 1, Issue 5, 84-87.

[18] Sum V., (2010), "Integrating training in business strategies means greater impact of training on the firm's competitiveness". Research in Business and Economics Journal, 1-19.
[19] Vemić J., (2007), "Employee Training and Development and the Learning Organization". Economics and Organization Vol. 4, No 2, 209- 216.

[20] Vijayaraj M., Malarvizhi M., Sasikumar P., (2012), "Study on Effectiveness of Training in Godrej Sara Lee Ltd, Puducherry." Indian Streams Research Journal, Vol.2, Issue. III, 1-6.

[21] Xiao Y., (2010), "The Importance of Staff Training in the Hotel Industry Case study: Renaissance Shanghai Yuyuan Hotel". University of Applied Sciences, Vol 2, 1-57.



C 2021 by the Sakshi Madaan, and Dr. Vinod Kumar Bhatnagar. Submitted for possible open access publication under the terms and conditions of the Creative Commons Attribution (CC BY) license (http://creativecommons.org/licenses/by/4.0/). 